\title{
Objectives and Principles of Administrative Proceedings: Doctrinal Ideas and Legislative Wordings of the Eastern European Countries
}

\author{
Boris V. Makogon ${ }^{1}$, Mihail I. Nikulin ${ }^{1}$, Valerij N. Samsonov ${ }^{1}$, Marina A. Sorokoletova ${ }^{1} \&$ Olesya O. Tovstukha ${ }^{1}$ \\ ${ }^{1}$ Belgorod State University, 85 Pobedy Street, Belgorod, The Belgorod Region, Russia \\ Correspondence: Boris V. Makogon, Belgorod State University, 85 Pobedy Street, Belgorod, The Belgorod \\ Region, 308015, Russia. E-mail: russia@prescopus.com
}

Received: June 19, 2017

Accepted: July 18, $2017 \quad$ Online Published: August 30, 2017

doi:10.5539/jpl.v10n4p221

URL: https://doi.org/10.5539/jpl.v10n4p221

\begin{abstract}
This article examines the theoretical approaches and legislative decisions of the Eastern European states' cocerning the purposes and principles of administrative proceedings. Based on the analysis of relevant scientific works and legislation, it has been concluded that both the objectives of administrative proceedings and its principles relate to the human rights and freedoms. At the same time, the doctrinally articulated objectives do not find their systematic reflection in the legislation, and the principles are a universal legal element that determines the relationships between the executive authorities and citizens.
\end{abstract}

Keywords: the administrative and procedural law, the objective of administrative proceedings, the principles of administrative proceedings, administrative procedures, human rights

\section{Introduction}

The process of improving public administration and increasing its efficiency is associated with the administrative process, the part of which is the administrative proceedings. Being a special type of administrative activity, it is connected with the resolution of a certain category of cases on the basis of general and special procedural norms. The administrative proceedings are investigated in the context of problems of administrative law (Seerden \& StroinkF, 2002) and its globalization (Kingsbury et al., 2005), in conjunction with the protection of rights of various categories of persons (BignamiF, 2003; O'Donnell, 2009), in connection with other problems (Finkelstein, 1973). At the same time, all of the above directions of the study of administrative proceedings are mediated by its goals and principles, which are considered in this paper.

\section{Methodology}

Various general scientific methods and methods of logical cognition are used in the paper: system, analysis and synthesis, abstraction, functional and formal-logical approaches. Achievement of the objective stated has been facilitated by the application of formal legal and comparative legal methods.

\section{Discussion and Results}

There are discussions about the goal-setting of administrative proceedings, which is conditioned by the requirements to a modern democratic state, in the doctrine of modern administrative law. Thus, Rusch W. outlined the following three objectives of administrative production: guaranteeing the rights and freedoms of a human and citizen through the practical implementation of constitutional rights and freedoms in the activities of executive bodies; guaranteeing the implementation of public interests through the implementation of the principle of transparency in the resolution of public administration issues (this will make it possible to increase the controllability of legal acts of executive bodies by the civil society institutions, the creation of a favorable investment climate and the conditions for economic development by establishing a regime for the stability of implementation of the executive power, predictability of its decisions and respect for the legitimate interests of citizens in the legal acts of executive authorities (Rusch, 2009). As it seems, the implementation of such objectives works in a comprehensive manner to minimize the human rights risks (Markhgeym, 2013).

Galligan D., Munkácsi Á., investigating the objectives of administrative proceedings, carry out their graduation by singling out two "particularly important" ones. These are the objectives of ensuring the effectiveness of the executive and administrative activities of the executive bodies and respect for the subjective rights and legitimate interests of citizens (Galligan \& Munkácsi, 1997). The first one directs the executive authorities to exercise their 
powers not only in accordance with the procedure established by law, but also in the most cost-effective and efficient way; the second one emphasizes the importance of the implementation of constitutional rights and freedoms of a human and citizen, as well as an equal and fair attitude of the executive authorities to the citizens in the executive and administrative activities. Here we shall emphasize the importance of the postulate of justice (Kuksin et al., 2016).

These ideas concerning the principles of administrative proceedings are reflected in the legislation of a number of Eastern European states. The objectives of administrative proceedings are deeply reflected in the Administrative Procedure Law of Latvia (Article 2), where the objectives of legislative regulation of administrative procedures are: a) ensuring observance of the basic principles of a democratic, rule-of-law state, especially the human rights, in the specific public-legal relations between the state and a private person; b) submission of actions of the executive power concerning the specific public-legal relations between a state and a private person to control of the independent, objective and competent judicial authorities; c) ensuring the legal, accurate and effective application of law in the public-legal relations.

The implementation of the objectives of administrative proceedings is ensured by a number of legal principles designed to establish a single normative standard that excludes the very possibility of arbitrariness of public authorities in relation to the citizens or their associations. Their legislative establishment serves as a guarantee to prevent illegal revision of such principles as a result of adoption of the departmental acts. At that, if the authorities do not observe the proclaimed principles, the citizen gets the opportunity to appeal it in to the higher authorities or in court. The principles governing administrative procedures are the specific reference points for the activities of numerous subjects of law, and they can fully fulfill their functions and purpose only by interacting with each other (Galligan, 2002). Practical implementation of these principles makes it possible to judge the effectiveness and viability of acts regulating the administrative procedures. The analysis the legislation of the Eastern European countries on administrative procedures makes it possible to single out a number of their general principles. Let us consider them.

The principle of respect for human rights. Its meaning lies in the fact that the executive authorities shall facilitate the implementation of the rights and legal interests of persons concerned with the adoption of legal acts and consideration of other cases attributed to their competence, especially at the decision-making stage, within the law. At that, Galligan D., Munkácsi Á. emphasize that this principle assumes that the consolidation of the so-called positive rights in the law automatically imposes obligations on the executive bodies on their implementation. When applying to the executive authorities, the applicant shall not depend on "the goodwill or decency of an official or authority" (Starostsyak, 1964). This principle is enshrined in the laws "On the Administrative Procedure" of Belarus (para. 3 of Article 4), Latvia (Article 5), Estonia (part $1 \S 3$ ), the Code "On the Administrative Proceedings" of Slovakia (part $1 \S 3$ ), the Code "On the Administrative Procedure" of the Czech Republic, in part 2 of Article 4 of which the duty of the executive authorities "to provide any person concerned with a reasonable advice on his rights and obligations, if this is necessary on the basis of the circumstances of a particular case" is established.

The consequences of the principle of respect for human rights in the administrative procedures are the requirements of proportionality (fairness) of administrative legal acts, the meaning of which is that the benefits, which a society can obtain from restrictions imposed on the addressee shall be greater than restrictions on the rights or legitimate interests of the addressee himself. This is enshrined in the laws "On the Administrative Procedure" of Latvia (Article 13), Estonia (part $2 \S 3$ ), similar Codes of the Czech Republic (part 3 of Article 2) and Slovakia (part $3 \S 4$ ). In addition, the Law "On the Administrative Procedure" of Latvia (Article 12) and the Code "On the Administrative Procedure" of the Czech Republic (part 4 of Article 2) have a demand to preserve the democratic character of the state and society.

It shall be noted that the principle of priority of human rights is not fixed in the legislation of the Republic of Lithuania, but the requirement of proportionality of administrative legal acts is established (para. 3 of Article 3 of the Law "On Public Administration").

The principle of equality. It lies in the fact that in cases with the identical factual and legal circumstances, institutions and courts shall take correspondingly identical decisions at administrative hearings, regardless of gender, race, language, color, religious belief, political and other views, social origin, nationality, education, social and financial status, occupation and other circumstances. It is enshrined in the laws "On the Administrative Procedure" of Belarus (para. 2 of Article 4), Latvia (Article 6), "On the Administrative Proceedings" of Slovakia (part 4 § 3), "On Public Administration" of Lithuania (para. 2 of Article 3), the Code "On the Administrative Procedure" of the Czech Republic (Article 7). Let us clarify that this principle is called the principle of objectivity in this Lithuanian law, which essentially assumes that the decision-making and other official actions of the executive body shall be impartial. 
The principle of legality. It obliges the executive authorities to follow the norms of law within their powers established by the regulatory decisions and to use their powers only in accordance with that appointment and for the purpose indicated in the relevant legal norms (laws "On the Basics of Administrative Procedure" of Belarus (para. 1 of Article 4), "On Public Administration" of Lithuania (para. 1 and 4 of Article 3), "On the Administrative Proceedings" of Slovakia (part 1 and 4 §), the Administrative Code of Poland (Article 6), the Code "On the Administrative Procedure" (Article 2) of the Czech Republic) (Galligan \& Munkácsi, 1997). At that, the Law of the Republic of Latvia "On the Administrative Procedure" specifies the principle of legality (Article 7) in relation to the application of the norms of law (Article 8 - reasonableness of the application of law), to the legal grounds for decisions and actions of executive authorities (Article 9 - principle of arbitrariness prohibition), the priority of laws in the activities of executive bodies (Article 14), to the activities of executive bodies (Article 10 - the principle of confidence in the legality of actions made). The requirement to implement administrative procedures in such a way as to increase confidence in the executive authorities is also enshrined in Art. 8 of the Administrative Code of the Republic of Poland.

The principle of openness of the administrative procedure. It involves the possibility for the person concerned to get acquainted with the materials related to the consideration of his application and to take part in the consideration of this application personally and (or) through his representatives (laws "On the Basics of Administrative Procedure" of Belarus (para. 4 of Article 4), "On the Administrative Procedure" of Estonia (§ 7), "On the Administrative Proceedings" of Slovakia (part $3 \S 3$ ), the Administrative Code of Poland (part $5 \S 3$ ), the Code "On the Administrative Procedure" of the Czech Republic (part 3 of Article 4).

The principle of promptness and accessibility of the administrative procedure (efficiency and procedural economy). It means the implementation of the administrative procedure as soon as possible with the submission of a minimum number of documents and (or) information for the implementation of the administrative procedure by the person concerned to the authorized body (Rusch, 2009). (the laws "On the Basics of Administrative Procedure" of Belarus (para. 5 of Article 4), "On Public Administration" of Lithuania (para. 6 and 7 of Article 3), "On the Administrative Procedure" of Estonia (part $3 \S 5$ ), "On the Administrative Proceedings" of Slovakia (part $3 \S 3$ ), the Administrative Code of Poland (Article 12), the Code "On the Administrative Procedure" of the Czech Republic (Article 6).

This principle also implies the implementation of administrative procedure in the form of a "one-stop shop", meaning that a request of the person concerned with the application to one authorized body with the attachment of documents and/or information necessary for the implementation of the administrative procedure, may be submitted only by the person concerned (laws "On the Basics of Administrative Procedure" of Belarus (para. 6 of Article 4), "On Public Administration" of Lithuania (para. 8 of Article 3). It shall be told that the requirement to organize an administrative procedure in the form of a "one-stop shop" is not a novelty for the activities of the executive authorities of Poland, Slovakia, the Czech Republic, and the states of the former SFRY (Socialist Federal Republic of Yugoslavia). Back in the mid-60's of the XX century Professor Starosciak E. noted the economic benefits, as well as the political effect of implementing this requirement (Starostsyak, 1964).

The principle of cooperation. In accordance with it, when implementing the administrative procedures, the authorized executive body shall interact with other state bodies and other organizations by sending requests and receiving documents and/or information necessary for the implementation of such procedures, as well as in other forms (laws "On the Basics of Administrative Procedures" of Belarus (para. 7 of Article 4), "On Public Administration" of Lithuania (para. 5 of Article 3), "On the Administrative Proceedings" of Slovakia (part $2 \S 3$ ), of the Administrative Code of Poland (Article 13), the Code "On the Administrative Procedure" of the Czech Republic (Article 8)).

The principles of administrative procedures are the most stable and universal element in the sphere of relations between the executive authorities and citizens. A characteristic feature of the totality of these principles is their interrelation (Salishcheva \& Abrosimova, 2002). That is why the vast majority of the acts on the administrative procedures being examined in the paper are not limited to the formulation and consolidation of one of the principles, but represents the whole system. Thus, the observance of one principle facilitates the implementation of others, as well as the violation of any of the principles automatically entails the non-observance of others. The principles of the administrative procedure, on the one hand, are intended to limit the framework of the judgment of the officials of public authorities, and on the other hand, to provide maximum freedom in implementing the rights and interests of individuals (Ekshtayn, 2002). Compliance with all the principles discussed above leads to a fair consideration of an individual-specific case and making a decision on it that would be in the interests of a particular citizen. 


\section{Conclusions}

The analysis of theoretical approaches and legal decisions concerning the administrative proceedings in the Eastern European countries gave grounds for a number of conclusions. The scientifically grounded goals of administrative proceedings are mediated by the humanitarian ideas that integrate the rights, freedoms, legitimate interests of individual citizens and civil society. In legal editions, they are presented mainly fragmentarily.

The principles that establish a uniform standard of administrative production are also mediated by the rights and freedoms and constitute an appropriate system, both in the theoretical development and in the legislative consolidation. The principles of administrative procedures are the most stable and universal element in the sphere of relations between the executive authorities and citizens.

\section{References}

Bignami, F. E. (2003). Three Generations of Participation Rights in European Administrative Proceedings. Jean Monnet Working Paper. Retrieved from http://scholarship.law.duke.edu/faculty_scholarship/708

Ekshtayn, K. (2002). The Administrative Procedure as the Basis of Administrative Process. Constitutional Law: Eastern European Review, 4(41), 147-150.

Finkelstein, M. O. (1973). Regression Models in Administrative Proceedings. Harvard Law Review, 86, 1442-1475. https://doi.org/10.2307/1340033

Galligan, D., \& Munkácsi, Á. (1997). Administrative Procedures and the Supervision of Administration in Hungary, Poland, Bulgaria, Estonia and Albania. Paris, 134 p.

Galligan, D., Polyanskiy, V. V., \& StarilovYu. N. (2002). Administrative Law: History of Development and Basic Modern Concepts. M., $410 \mathrm{p}$.

Kingsbury, B., Krisch, N., \& Stewart, R. (2005). Law and Contemporary Problems. The Emergence of Global Administrative Law, 68(3/4), 15-61.

Kuksin, I. N., Markhgeym, M. V., Novikova, A. E., \& Tonkov, E. E. (2016). Justice as Principle: Aspects of Genesis in Social and Regulatory Systems. The Social Sciences, 11, 2367-2370.

Markhgeym, M. V., \& Novikova, A. E. (2013). TonkovE.E. Human Rights: a Sight in the Light of Advocacy Risks. World Applied Sciences Journal, 27(1), 74-77.

O'Donnell, D. (2009). The Right of Children to be Heard: Children's right to have their views taken into account and to participate in legal and administrative proceedings. Innocenti Working Paper № 2009-04. UNICEF Innocenti Research Centre, Florence, 62 p.

Rusch, W. (2009). Administrative Procedures in EU Member States. Conference on Public Administration Reform and European Integration. Budva, Montenegro, 26-27 March 2009. Budva, 2009. pp. 41-51.

Salishcheva, N., \& Abrosimova, E. (2002). On the Problems of Forming the Institute of Administrative Procedure in the Russian Federation. Constitutional Law: Eastern European Review, 4(41), 133-135.

Seerden, R., \& Stroink, F. A. M. (2002). Administrative law of the European Union, its member states and the United States: a comparative analysis. Vol. 39.

Starostsyak, E. (1964). Institutes of the Administrative Process of the European Socialist Countries. Soviet State and Law, 7, 128-129.

\section{Copyrights}

Copyright for this article is retained by the author(s), with first publication rights granted to the journal.

This is an open-access article distributed under the terms and conditions of the Creative Commons Attribution license (http://creativecommons.org/licenses/by/4.0/). 